\title{
Lack of influence of low temperature, light and growth substances on phytochrome resynthesis in coleoptiles of irradiated oat seedlings
}

\author{
JAN KOPCEWICZ, MARIUSZ CYMERSKI, KAZIMIERZ MADELA
}

Laboratory of Photobiology, Department of Plant Physiology, Institute of Biology, N. Copernicus University, Gagarina 9, 87-100 Toruń, Poland

(Received: November 25, 1983. Accepted: December 20, 1983)

Abstract

\begin{abstract}
The photoconversion of phytochrome $P_{R}$ into the $P_{F R}$ form causes at the same time the destruction of the initial large fraction of phytochrome found in the coleoptiles of etiolated oat seedlings. Factors such as low temperature, light of different wavelengths or growth substances are not capable of preventing the progressive destruction and restore the synthesis of phytochrome. Thus an abnormally high level of phytochrome is found only in etiolated seedlings. Such seedlings, on the other hand, are characterized by a very high rate of elongation growth. The role of phytochrome in the control of deetiolation of seedlings is discussed.
\end{abstract}

Key words: phytochrome metabolism, growth substances, oat coleoptiles.

\section{INTRODUCTION}

It has been found previosly that in the coleoptiles of etiolated oat seedlings phytochrome is present etirely in the $P_{R}$ form which seems to be stable. The $\mathrm{P}_{\mathrm{FR}}$ form is relatively unstable and in darkness it progressively disappears either by breakdown or conversion to an unknown substance which does not display photoreversibility. These processes lead to a fall in the total phytochrome level (Ko p ce wi c z and Cy mer$\mathrm{ski}$ 1983). Irradiation of the seedlings with either white or monochromatic light leads to a decay in the total amount of phytochrome. The rate of destruction depends on the quality of light arousing phytochrome ( $\mathrm{K}$ o p c e w i c z et al. 1983a). Growth substances like IAA, $\mathrm{GA}_{3}$, kinetin, ABA and ethrel do not influence the rate of phytochrome destruction. Inhibitors of energy-producing processes like KCN, 2,4-DNP, DCCD and 
antimycin A inhibit partly the process of dark destruction of the $\mathrm{P}_{\mathrm{FR}}$ form of phytochrome (K o p c e w i c z et al. 1983b).

The results mentioned above show that photoconversion of $\mathrm{P}_{R}$ into $\mathrm{P}_{\mathrm{FR}}$ causes at the same time a rapidly increasing destruction of phytochrome. From that moment a considerable increase in the total amount of phytochrome has not been observed again. This suggests indirectly the occurence of two phytochrome populations in the coleoptiles of oat seedlings.

The aim of the present investigations was to check whether there is a possibility of stimulating resynthesis of the initial large fraction of phytochrome which is found in etiolated seedlings of monocotyledonous plants.

\section{MATERIAL AND METHODS}

Oat seeds (Avena sativa L. variety Diadem) were soaked in distilled water for 1 hour and afterwards sown into moist, sterilized sawdust of deciduous trees. The germination of seeds and the cultivation of seedlings were conducted in darkness, at $+26^{\circ} \mathrm{C}$. 96 hours after sowing the whole seedlings were irradiated with active red light $(660 \mathrm{~nm})$ for 15 minutes (1st irradiation). Then, the effect of low temperature, light of different wavelengths and growth regulators on phytochrome resynthesis was investigated.

In investigations on low temperature, red light irradiated seedlings were kept initially for 4 hours in darkness at $+26^{\circ} \mathrm{C}$ and then the temperature was changed to $+5^{\circ} \mathrm{C}$. The seedlings were incubated under these conditions for 24 hours. The content of phytochrome was determined just before and after irradiation, after 4 hours of incubation at $+26^{\circ} \mathrm{C}$, and then at two-hour intervals during incubation at low temperature.

In investigations on the effect of light on phytochrome resynthesis the red light-irradiated seedlings (1st irradiation) were kept during 12 hours in darkness at $+26^{\circ} \mathrm{C}$. Afterwards they were irradiated for 20 minutes (2nd irradiation) with monochromatic light at wavelengths of $450,500,660$ and $750 \mathrm{~nm}$. For irradiation of the plant material a lamp with a $2500 \mathrm{~W}$ xenon burner equipped with monochromatic filters was used. The intensity of irradiation was: $195 \mu \mathrm{W} \cdot \mathrm{cm}^{-2}$ at $450 \mathrm{~nm}$, $190 \mu \mathrm{W} \cdot \mathrm{cm}^{-2}$ at $500 \mathrm{~nm}, 170 \mu \mathrm{W} \cdot \mathrm{cm}^{-2}$ at $660 \mathrm{~nm}$ and $140 \mu \mathrm{W} \cdot \mathrm{cm}^{-2}$ at $730 \mathrm{~nm}$. After the second irradiation the seedlings were placed in darkness, at $+26^{\circ} \mathrm{C}$ for 4 hours. The content of phytochrome was determined after the first irradiation, after 12 hours of incubation, then after the second irradiation and 4 hours of incubation after the second irradiation.

In investigations on the influence of growth regulators on phytochrome resynthesis the red light-irradiated seedlings were kept during 
4 hours in darkness at $+26^{\circ} \mathrm{C}$. Afterwards they were treated with a water solution of growth regulators. Kinetin, indole-3-acetic acid (IAA), gibberellic acid $\left(\mathrm{GA}_{3}\right)$, abscisic acid $(\mathrm{ABA})$ ethrel and acetylcholine ( $\mathrm{ACh}$ ) were applied at the concentration of $10^{-3} \mathrm{M}$. The seedlings were incubated in the solution of growth regulators for 20 hours. The phytochrome content was measured directly before and immediately after irradiation of seedlings and then after 4 hours of incubation in water without growth substances and after 5, 10 and 20 hours of incubation in the solutions of growth regulators.

The content of phytochrome was measured in $5 \mathrm{~mm}$-long coleoptile tips isolated from exactly 100 seedlings. The measurement was done spectrophotometrically and the level of phytochrome was calculated from the difference in the optical density of the tissuse ( $\triangle O D$ ) at 660 and $730 \mathrm{~nm}$ according to the method previously described (B u t l e r et al. 1959, $\mathrm{K}$ o p cewicz and Cymerski 1983). The modified double-beam spectrophotometre SPECORD UV-VIS with a connected convertor of TEC-1 extinction, enabling the numerical reading of optical density with an accuracy up to $10^{-3}$, was used. Irradiation with active monochromatic light $(660$ and $730 \mathrm{~nm})$ during phytochrome measurement was done with a Diaprex B-10 projector with $150 \mathrm{~W}$ halogen bulb.

The coleoptiles were cut and isolated and the measurement cell was filled, on a thermostatic aluminium plate ensuring constant temperature of $0^{\circ} \mathrm{C}$. All the manipulations were done under dim green light.

Statistical analysis was based on three independent analytical replications (3 sample of 100 coleoptiles for phytochrome measurement). Every measurement was repeated 5 times.

\section{RESULTS AND DISCUSSION}

Both our previous investigations (Kopcewicz and $\mathrm{Cymerski}$ 1983, Kopcewicz et al. 1983a, b) and the data of other authors (Chorney and Gordon 1966, Dooskin and Mancinelli 1968, Frankland 1972) show that coleoptiles of young etiolated seedlings of oat and of other monocotyledonous plants contain an abnormally high level of phytochrome, found as a whole in the $P_{R}$ form. Irradiation of seedlings with white or monochromatic light causing photoconversion of the pigment into the $\mathrm{P}_{\mathrm{FR}}$ form leads at the same time to a rapid decrease in the total amount of phytochrome to about 10 per cent of its initial value. Since in irradiated seedlings a considerable increase in the total content of phytochrome has not been observed again, it is suggested that in seedlings there exist two, qualitatively different, phytochrome popula-tions (Purves and Briggs 1968, Everett et al. 1970, Bois- 
s a r d et al. 1971). The first population is the original large fraction of phytochrome in seeds and etiolated seedlings and the second one is the small active fraction masked in etiolated seedlings by the first population of phytochrome. Thus, the question arises whether there is a possibility of resynthesis of the large fraction of phytochrome in non-etiolated seedlings. In order to find the answer to this problem, experiments on the influence of low temperature (Fig. 1), light of different wavelengths (Fig. 2) and growt substances applied exogenously (Fig. 3) on the kinetics of phytochrome transformation in darkness were performed.

The results (Fig. 1) show that irradiation with red light causes both photoconversion and rapid destruction of phytochrome in oat seedlings. If the temperature is lowered to $+5^{\circ} \mathrm{C}$ the process of destruction of phytochrome is impeded. However, during 24 hours of action of low temperature symptoms of phytochrome reappearance have not been oberved.

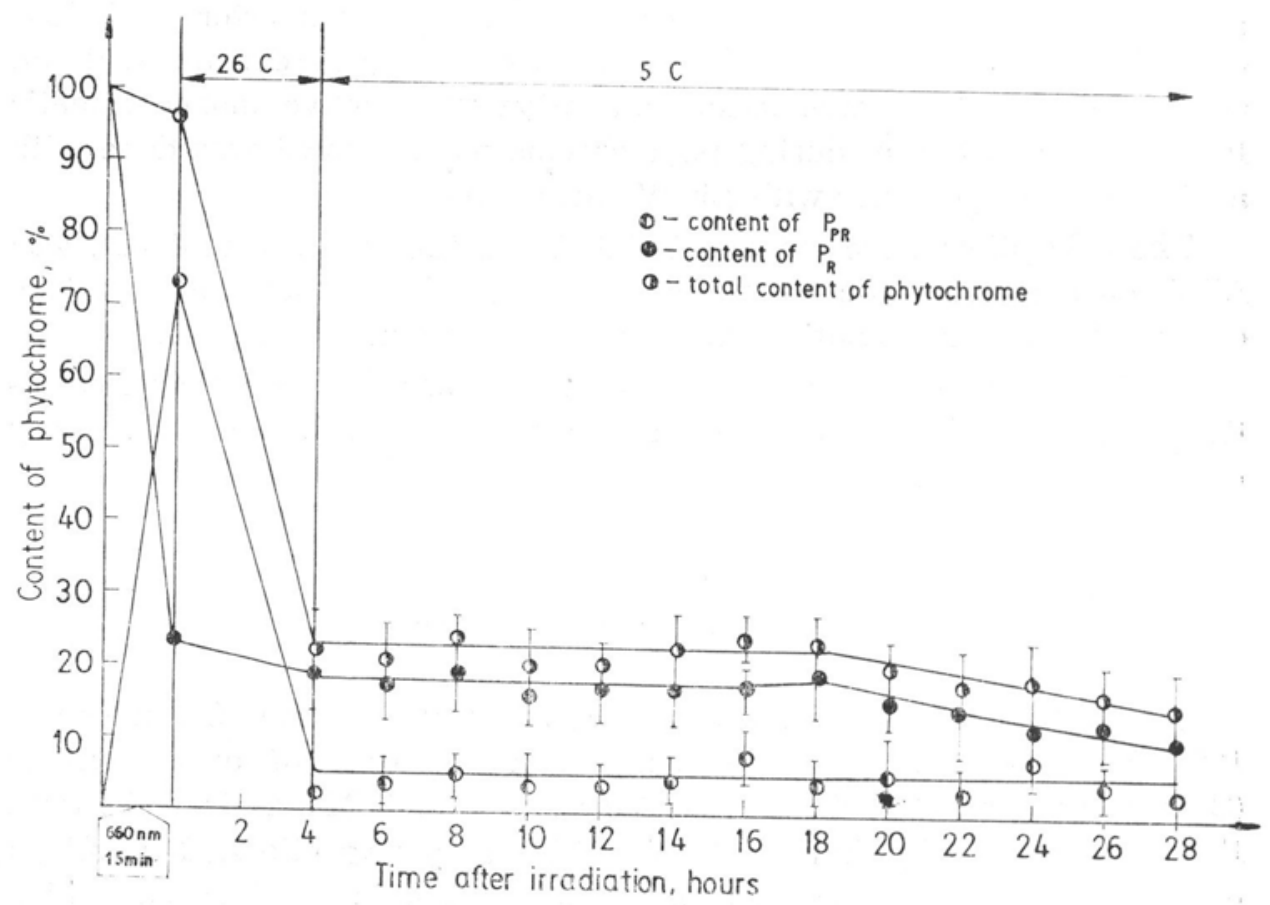

Fig. 1. Influence of low temperature on phytochrome resynthesis in coleoptiles of irradiated oat seedlings

The results of experiments on the influence of different ranges of the light spectrum on phytochrome resynthesis (Fig. 2) show that during 12 hours after the first irradiation with red light the content of the $P_{F R}$ form of phytochrome falls to unmeasurable values while that of $P_{R}$ to about 15 per cent of the initial value. During the second irradiation and 
in the following period of darkness a further decrease in the content of the $\mathrm{P}_{\mathrm{R}}$ form of phytochrome continues, dependent on the wavelength of the applied light. Thus, the irradiation of oat seedlings with monochromatic light different wavelengths did not cause phytochrome resynthesis in coleoptiles of oat seedlings. It is worth noting that, in spite of repeated irradiations of seedlings with red light $(660 \mathrm{~nm})$ no measurable photoconversion of $P_{R}$ in'to the $P_{F R}$ form of phytochrome was observed. Probably this is due to the destruction of phytochrome simultaneous with photoconversion.

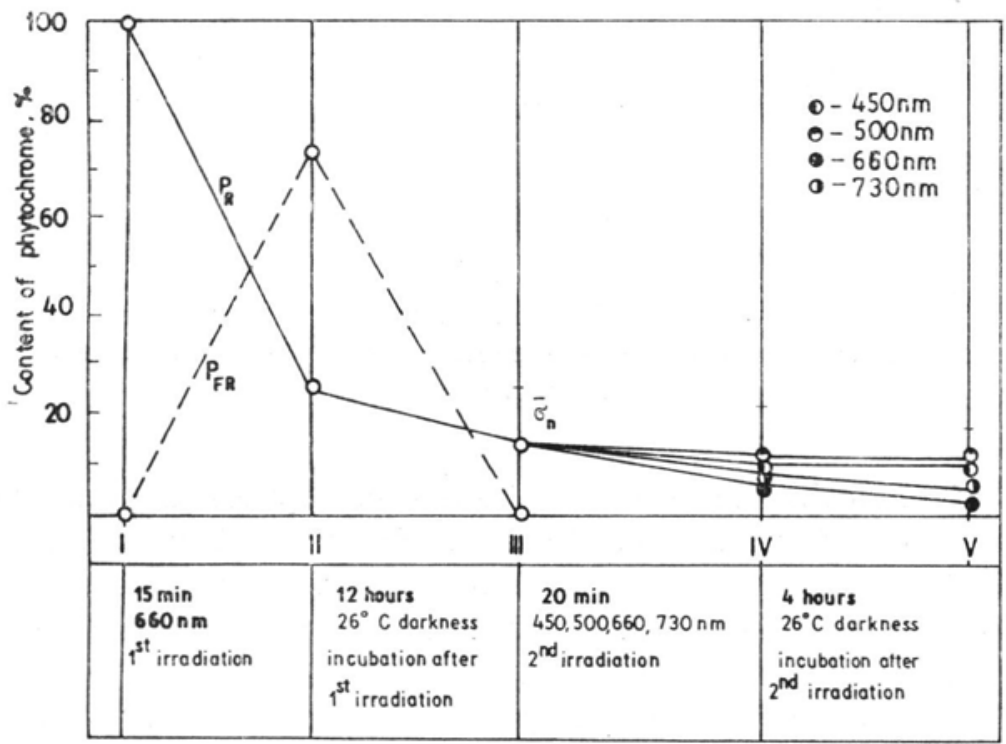

Fig. 2. Influence of monochromatic light of different wavelengths on phytochrome resynthesis in coleoptiles of irradiated oat seedlings

The results of experiments on the influence of growth substances (Fig. 3) show that growth hormones are not capable of stimulating phytochrome resynthesis. Growth substances do not influence, in a noticeable way, dark transformation of phytochrome. Independently of the growth substances applied phytochrome undergoes successive destruction. In the experiments all growth regulators were applied in the concentration of $10^{-3} \mathrm{M}$. Although it is a high dose, owing to the relatively short time of incubation negative effects on the plant tissues were not observed. During preliminary experiments other concentrations of growth substances $\left(10^{-4}-10^{-6}\right)$ were applied, but without influence on the course of phytochrome resynthesis.

The obtained results show that photoconversion of phytochrome $P_{R}$ into the $P_{F R}$ form causes at the same time destruction of the initial large 


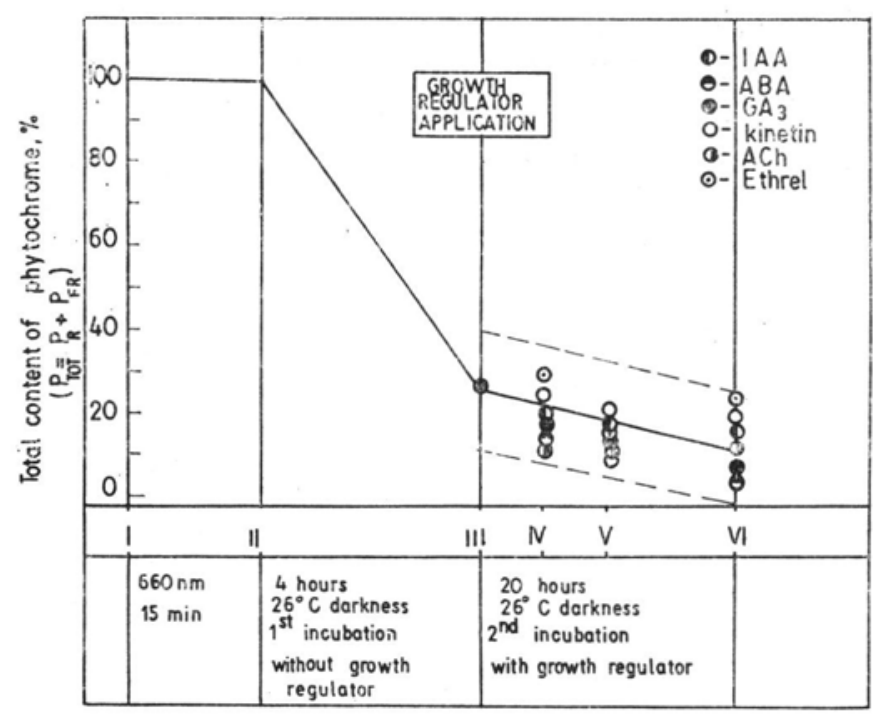

Fig. 3. Influence of growth regulators on phytochrome resynthesis in coleoptiles of irradiated oat seedlings. insignificant

fraction of phytochrome occurring in the coleoptiles of etiolated oat seedlings. None of the applied factors such as low temperature, monochromatic light of different wavelengths, or growth substances stimulated phytochrome resynthesis. These results seems to confirm the earlier reports suggesting the existence in seedlings of different phytochrome populations (Purves and Briggs 1968, Everett et al. 1970, Boissard et al. 1971). In the coleoptiles of oat seedlings there may exist two different phytochrome populations which are linked with two different expressions of phytochrome activity. The first one is connected with the destruction of an originally large fraction of phytochrome and controls the process of deetiolation of seedlings only. The second one is linked with the process of photoconversion and dark reversion of a small fraction of phytochrome which does not undergo destruction. It seems possible that this small fraction of phytochrome controls the metabolic processes connected with further development of seedlings and morphogenesis of mature plant.

The suggestions presented above are working hypotheses and they require experimental confirmation. Especially the problem of the possible contribution of the original large fraction of phytochrome in controlling the process of deetiolation of seedlings requires further explanation. If such an assumption is true a correlation between this fraction of phytochrome and growth substances which take part in the control of the deetiolation is to be expected. 
The results here presented show that the process of destruction of the high content of phytochrome is irreversible and the abnormally high level of phytochrome occurs solely in etiolated seedlings. A At the same time, only etiolated seedlings show an unnaturally intensive elongation growth. The correlation between these two phenomena suggests the role of phytochrome in the control of elongation growth and deetiolation of oat seedlings.

\section{Acknowledgment}

Research supported by grant within project MR II/7-5.1.4.

\section{REFERENCES}

Boissard J., Marme D., Schäfer E., 1971. The demonstration in vivo of more than one form of $\mathrm{P}_{\mathrm{fr}}$. Planta 99: 302-310.

Butler W. L., Norris K. H., Siegelman H. W., Hendricks S. B., 1959. Detection, assay and preliminaty purification of the pigment controlling photoresponsive development of plants. Proc. Nat. Acad. Sci. USA 45: 1703-1708.

Chorney W., Gordon S. A., 1966. Action spectrum and characteristics of the light activated disappearance of phytochrome in oat seedlings. Plant Physiol. 41: 891-896.

Dooskin R. H., Mancinelli A. L., 1968. Phytochrome decay and coleoptile elongation in Avena following various light treatments. Bull. Torrey Botan. Club 95: 474-487.

Everett M. S., Briggs W. R., Purves W. K., 1970. Kinetics of phytochrome phototransformation. A re-examination. Plant Physiol. 45: 805-806.

Frankland B., 1972. Biosynthesis and dark transformations of phytochrome. In: Phytochrome. K. Mitrakos and W. Shropshire Jr. (eds.), Academic Press, London-New York, pp. 195-229.

Kopcewicz J., Cymerski M., 1983. Non-photochemical transformation of phytochrome in coleoptiles of etiolated oat seedlings. Acta Physiol. Plant. 5: 3-9.

Kopcewicz J., Cymerski M., Madela K., 1983a. Light-induced transformation of phytochrome in the coleoptiles of oat seedlings. Acta Physiol. Plant. 5: $133-142$.

Kopcewicz J., Cymerski M., M a dela K., 1983b. Influence of growth regulators and respiration inhibitors on dark transformation of phytochrome in coleoptiles of oat seedlings. Acta Soc. Bot. Pol. 52: 139-148.

Purves W. K., Briggs W. R., 1968. Kinetically distinguishable populations of phytochrome. Plant Physiol. 43: 1259-1263. 
Brak wplywu niskiej temperatury, światla i substancji wzrostowych na resynteze fitochromu $w$ koleoptylach napromieniowanych siewek owsa

\section{Streszczenie}

Fotokonwersja fitochromu $\mathrm{P}_{\mathrm{R}}$ do formy $\mathrm{P}_{\mathrm{FR}}$ powoduje jednocześnie destrukcję początkowej dużej puli fitochromu występującej w koleoptylach etiolowanych siewek owsa. Czynniki takie jak obniżona temperatura, światło o różnej długości fali, czy substancje wzrostowe, nie są w stanie zapobiec postępującj destrukcji i spowodować resyntezę fitochromu. Anormalnie wysoki poziom fitochromu występuje więc wyłącznie w etiolowanych siewkach. Siewki takie charakteryzują się również nienaturalnie wysokim tempem wzrostu wydłużeniowego. W pracy dyskutuje się udział fitochromu w kontroli deetiolacji siewek. 